\title{
PENGGUNAAN SMARTPHONE DAN LOCUS OF CONTROL: KETERKAITANNYA DENGAN PRESTASI BELAJAR, KUALITAS TIDUR DAN SUBJECTIVE WELL-BEING
}

\author{
Dedy Susanto \\ Badan Pusat Statistik Provinsi Papua, Jayapura \\ Email: dedy.susanto@bps.go.id
}

\begin{abstract}
Abstrak
Penelitian ini memiliki tujuan untuk mengetahui pengaruh frekuensi penggunaan smartphone dan locus of control (LOC) terhadap penggunaan smartphone disaat tidak tepat (waktu tidur dan belajar sendiri), prestasi belajar, dan subjective well-being (SWB). Penelitian ini mengumpulkan sebanyak 342 mahasiswa diambil dengan metode circular systematic random sampling dan diminta mengisi kuesioner penelitian yang telah tervalidasi. Path Analysis digunakan untuk memeriksa pengaruh penggunaan smartphone dan LOC terhadap beberapa variabel yang dipilih. Berdasarkan hasil uji kesesuaian model, covariance model tidak berbeda signifikan terhadap covariance sampel (good fit). Analisis utama penelitian ini menunjukkan bahwa penggunaan smartphone harian berpengaruh terhadap penggunaan smartphone diwaktu tidak tepat, kualitas tidur, dan SWB. Sedangkan LOC berpengaruh terhadap aktivitas penggunaan smartphone diwaktu tidur, kualitas tidur, dan SWB. Penelitian ini menyimpulkan bahwa semakin meningkatnya penggunaan smartphone harian akan meningkatkan penggunaan smartphone diwaktu yang tidak tepat, menurunkan kualitas tidur, dan menurunkan SWB. Selanjutnya, semakin internal LOC, semakin rendah penggunaan smartphone diwaktu tidur, meningkatnya kualitas tidur, dan meningkatnya SWB.
\end{abstract}

Kata kunci: kualitas tidur, locus of control (LOC), penggunaan smartphone, prestasi belajar, subjective well-being.

\begin{abstract}
This research aimed to investigate the effect of smartphone usage frequency and locus of control (LOC) on smartphone activity at inappropriate times (sleep and self-study), learning achievement, and subjective well-being (SWB). This study employed 342 students as participants to fill the questionnaire. Participants were selected by systematic random sampling method. Path Analysis is used to check the effect of smartphone and LOC on selected outcome variables. Based on the model goodness of fit, covariance model is not significantly different to sample covariance; and based on a test of significance. Main analysis revealed that smartphone usage frequency influenced improper smartphone activity, sleep quality, and SWB. Similarly, we found that LOC influenced smartphone usage activity at bedtime, sleep quality, and SWB. This study concluded that increasing daily usage of smartphones will increase smartphone usage at improper times, decrease sleep quality and SWB. Furthermore, the more internal the LOC, the lower the use of smartphones during sleep times, increased sleep quality and SWB.
\end{abstract}

Keywords: academic performance; locus of control (LOC); sleep quality; smartphone usage, subjective well-being. 


\section{Pendahuluan}

Pada era saat ini, kebutuhan akan alat berteknologi modern sangat dibutuhkan oleh manusia untuk mempermudah pekerjaan sehari-hari. Salah satu teknologi yang sering digunakan pada saat ini adalah smartphone. Smartphone memiliki fungsi yang bermacam-macam seperti: alat komunikasi, akses informasi, hiburan, manajemen, dll. Banyak orang-orang diberbagai wilayah dunia menggunakan smartphone. Salah satunya wilayah tersebut tersebut adalah Indonesia.

Indonesia merupakan negara pengguna smartphone yang tinggi. Data TNS Infratest Germany mencatat $43,3 \%$ penduduk Indonesia menggunakan smartphone dan 3,9\% menggunakan tablet (smartphone yang memiliki layar lebih lebar) pada bulan Maret tahun 2015. Lalu, data Vserv Smart Data mengungkapkan rata-rata pengguna smartphone di Indonesia menghabiskan waktu sebanyak 129 menit per harinya. Dari fakta tersebut dapat diketahui bahwa penggunaan internet di Indonesia cukup besar.

Menurut data dari TNS Infratest Germany pengguna dengan kelompok umur kurang dari 25 tahun mayoritas menggunakan smartphone dengan persentase hampir $80 \%$ pada Mei 2015 . Dari data diatas, kelompok umur yang paling terekspos smartphone ialah usia kurang dari 25 tahun yang merupakan kelompok remaja. Oleh karena itu, dengan banyaknya pengguna smartphone dikalangan remaja, maka remaja akan memiliki peluang yang tinggi untuk terpapar dampak negatif dari penggunaan smartphone, seperti: menurunnya prestasi belajar (Jacobsen \& Forste, 2011), penurunan kuantitas dan kualitas tidur (Lanaj, Johnson, \& Barnes, 2014), buruknya kesehatan mental (Harwood, Dooley, Scott, \& Joiner, 2014), mengurangi olahraga kardio (Barkley, Lepp, \& Salehi-Esfahani, 2015), mengurangi tingkat kepuasan hidup (Lepp, Barkley, \& Karpinski, 2014).
Beberapa penelitian sebelumnya telah menjelaskan pengaruh penggunaan smartphone terhadap dampak negatif yang ditimbulkan dan sangat penting untuk mengeksplorasi lebih jauh latar belakang hubungan tersebut terutama lewat sisi psikologis. Sisi psikologis yang menjadi perhatian khusus dalam penelitian ini adalah locus of control (LOC) dari seseorang/individu. Lalu, besarnya penggunaan smartphone di kalangan remaja membuat peneliti tertarik untuk mengkaji lebih mendalam pengaruh LOC terhadap penggunaan smartphone remaja khususnya mahasiswa; dan bagaimana pengaruhnya keduanya terhadap beberapa outcome yang paling dekat dalam kehidupan mahasiswa sehari-hari seperti prestasi belajar, kualitas tidur, dan penilaian kualitas hidup subjektif yang diukur dari tingkat subjective well-being (SWB).

Dalam studi kasus yang telah dilakukan, terdapat banyak studi terdahulu yang meneliti tentang pengaruh penggunaan smartphone dan LOC terhadap prestasi belajar, kualitas tidur, dan SWB, namun pengujiannya hanya melibatkan 23 variabel, sehingga hanya memeriksa hubungan sederhana antarvariabel. Untuk itu, peneliti akan menguji secara simultan semua variabel yang diteliti sehingga diharapkan akan terciptanya model dan hasil analisis statistik yang lebih lengkap.

Dengan demikian, penelitian ini bertujuan untuk: (1) Mengetahui gambaran penggunaan smartphone, LOC, prestasi belajar, kualitas tidur, dan subjective wellbeing; serta (2) Menganalisis secara simultan pengaruh penggunaan smartphone dan LOC terhadap prestasi belajar, kualitas tidur, dan subjective wellbeing.

Kajian Teori. Locus of control (LOC) merupakan suatu persepsi kejadian oleh seseorang baik merupakan hasil dari tingkah lakunya maupun faktorfaktor lingkungan yang memengaruhinya, seperti keberuntungan, takdir, dan sebagainya. Seseorang yang merasa segala 
tindakan disebabkan oleh kejadian tertentu seperti keberuntungan, kesempatan, takdir, kendali dari orang lain yang kuat, atau sesuatu yang tidak dapat diprediksi yang disebabkan kekuatan yang mengelilinginya merupakan seseorang yang memiliki LOC eksternal. Namun, jika individu tersebut memiliki persepsi bahwa suatu kejadian disebabkan oleh tindakan atau sifat/karakteristik dirinya sendiri, maka dapat disimpulkan dia memiliki pengendalian internal (Rotter, 1966).

Selanjutnya, prestasi belajar merupakan suatu pembangunan multidimensi (Stipek \& Weisz dalam Pop, NegruSubtirica, Crocetti, Opre, \& Meeus, 2016), lebih banyak dioperasikan pada penilaian remaja yang didapatkan di sekolah, khususnya pada Indeks Prestasi (Poropat dalam Pop dkk., 2016). Salah satu indikator pengukuran prestasi belajar mahasiswa adalah Indeks Prestasi (IP). IP merupakan indikator prestasi belajar yang reliabel (Bacon \& Bean dalam Pop dkk., 2016) dan merupakan prediktor yang kuat untuk beberapa hasil yang penting seperti prestasi belajar (Kuncel dalam Pop dkk., 2016), performa kerja (Roth dalam Pop dkk., 2016), dan status pekerjaan (Strenze dalam Pop dkk., 2016).

Lalu, Jarvis dalam Naibaho (2013), Kualitas tidur merupakan kemampuan seseorang untuk mempertahankan tidur dan bangun dengan jumlah Rapid Eye Movement (REM) dan Non-rapid Eye Movement (NREM); merupakan siklus tidur yang terdiri empat tahap yang menunjukan perlambatan denyut jantung dan laju pernafasan, gerakan mata yang lambat, relaksasinya otot kecuali otot wajah dan leher (DeLaune \& Ladner, 2002). Kualitas tidur dipengaruhi oleh faktorfaktor seperti (DeLaune \& Ladner, 2002): tingkat kenyamanan, kecemasan, lingkungan, gaya hidup, makanan, obat, dan norma budaya.

Terakhir, Diener, Oishi, dan Lucas (2003) mendefinisikan Subjective Wellbeing (SWB) sebagai analisis ilmiah untuk mengetahui evaluasi hidup sese- orang baik pada waktu tertentu maupun periode yang lama seperti evaluasi hidup pada tahun sebelumnya. Diener dkk. (2003) mengungkapkan beberapa faktorfaktor yang memengaruhi SWB, yaitu: tujuan, tabiat dan kepribadian, kualitas hubungan sosial, pemenuhan kebutuhan dasar, kesehatan, demografi, sumber daya, kebudayaan, pendapatan, dan standar perbandingan.

Ada banyak penelitian terkait yang meneliti tentang pengaruh LOC terhadap penggunaan smartphone, prestasi belajar, kualitas tidur, dan SWB. LOC eksternal memiliki hubungan yang signifikan dengan ketergantungan dengan smartphone (Park, Kim, Shon, \& Shim, 2013). Kontras dengan penelitian lain, Chak dan Leung (2004) menemukan bahwa seseorang yang percaya adanya kekuatan kuat yang mengontrol kehidupannya cenderung memiliki hubungan yang positif terhadap ketagihan internet (salah satunya mengakses lewat media smartphone. Mereka merupakan individu yang memiliki lokus pengendalian eksternal yang kuat. Mereka akan kesulitan dalam mengatur penggunaan internet dan membahayakan hubungannya terhadap orang lain, pekerjaan, pendidikan, karir, dll. Fini dan Yousefzadeh (2011) menyatakan bahwa terdapat hubungan signifikan yang positif antara LOC internal dan prestasi belajar. Selanjutnya, semakin tinggi tingkat persepsi kontrol diri maka akan meningkatkan kualitas tidur seseorang (Vincent, Walsh, \& Chiang, 2013), penggunaan smartphone juga dihubungkan dengan insomnia dan gangguan tidur (Jenaro dalam Sahin, Ozdemir, Unsal, \& Temiz, 2013; Al-Khleiwi dalam Sahin dkk., 2013). Terakhir, Klonowicz (2001) menemukan bahwa seseorang yang memiliki LOC eksternal dilaporkan memiliki tingkat SWB yang lebih rendah dibandingkan yang internal.

Dari beberapa studi terkait, peneliti menemukan bahwa kebanyakan penelitian selama ini hanya menguji penggunaan smartphone dan LOC terhadap 


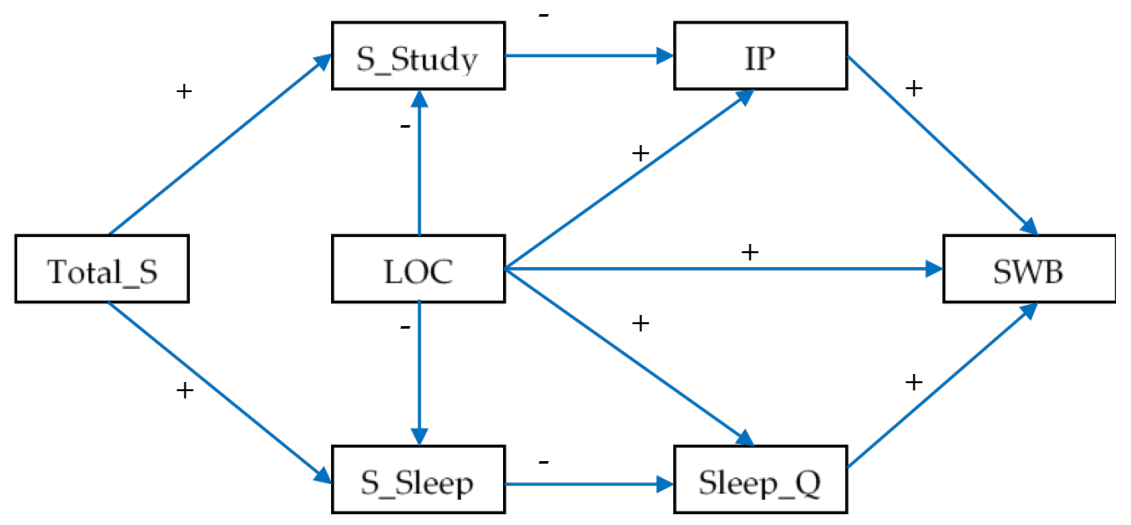

Gambar 1. Model path analysis berdasarkan hipotesis

prestasi belajar, kualitas tidur, dan SWB secara terpisah-pisah dan juga membangun model yang sederhana yang hanya menjelaskan hubungan sebab-akibat dua sampai tiga variabel. Ditambah, belum ditemukannya studi yang menjelaskan beberapa faktor terkait pada satu model struktural yang memuat interaksi antarvariabel. Untuk itu, peneliti membangun model struktural yang lebih kompleks, melibatkan tujuh variabel untuk diuji sekaligus sehingga model tersebut diharapkan dapat menjelaskan semua interaksi antarvariabel yang diteliti.

Berikut model penelitian yang dibangun peneliti dengan memperhatikan integrasi model path analysis yang menerangkan hubungan antarvariabel berdasarkan model statistik Li, Lepp, dan Barkley. (2015) yang terlihat pada Gambar 1.

Berdasarkan model penelitian tersebut, maka dibangunlah beberapa hipotesis yang menunjukan pengaruh antarvariabel, yakni sebagai berikut: (1) $\mathrm{H}_{1}$ dan $\mathrm{H}_{2}$ : total waktu penggunaan smartphone (Total_S) memiliki pengaruh positif terhadap penggunaan smartphone disaat belajar sendiri (S_Study) dan diwaktu tidur (S_Sleep); (2) $\mathrm{H}_{3}$ dan $\mathrm{H}_{4}$ : LOC internal memiliki pengaruh negatif terhadap penggunaan smartphone disaat belajar sendiri (S_Study) dan diwaktu tidur (S_Sleep); (3) $\mathrm{H}_{5}$ dan $\mathrm{H}_{6}$ : penggunaan smartphone diwaktu tidur
(S_Sleep) memiliki pengaruh negatif terhadap kualitas tidur (Sleep_Q) dan locus of contol (LOC) internal memiliki pengaruh positif terhadap kualitas tidur (Sleep_Q); (4) $\mathrm{H}_{7}$ dan $\mathrm{H}_{8}$ : penggunaan smartphone disaat belajar sendiri (S_Study) berpengaruhi negatif terhadap prestasi belajar (IP) dan LOC internal memiliki pengaruh positif terhadap prestasi belajar; terakhir, (5) $\mathrm{H}_{9}, \mathrm{H}_{10}$, dan $\mathrm{H}_{10}$ : semakin buruk kualitas tidur (Sleep_Q) memiliki pengaruh negatif terhadap subjective well-being (SWB) dan prestasi akademik, serta semakin internal LOC berpengaruh positif terhadap subjective well-being (SWB).

\section{Metode Penelitian}

Partisipan. Populasi pada penelitian ini adalah Mahasiswa Sekolah Tinggi Ilmu Statistik (STIS) Tahun Ajaran 2015/2016 yang masih remaja dengan rentang usia 17-23 tahun ( $\mathrm{N}=1929)$. Ternik pengambilan sampel yang digunakan adalah Circular Systematic Random Sampling. Batas kesalahan yang diambil peneliti adalah 0,05 $(\alpha=5 \%)$. Berdasarkan penghitungan menggunakan rumus Cochran, jumlah sampel minimum yang dibutuhkan untuk mencapai batas kesalahan sebesar 0,05 adalah 321 sampel. Kemudian, dalam mengantisipasi terjadinya nonrespon, peneliti memutuskan untuk meningkatkan jumlah sampel menjadi 350 sampel. 
Desain. Penelitian ini menggunakan desian Survey Research. Hal ini dilakukan disebabkan pengambilan sampel telah menggunakan teknik pengambilan sampel yang acak, serta analisis lanjutan menggunakan analisis statistik inferensia yang membutuhkan keacakan data untuk mengestimasi nilai parameter populasi.

Prosedur. Selama satu bulan kuesioner dibagikan ke 350 mahasiswa yang tersebar di 54 kelas di Sekolah Tinggi ilmu Statistik (STIS) selama bulan Juni 2016. Sampai waktu pengumpulan data berakhir, terdapat 8 responden yang tidak menyerahkan kuesioner penelitian, sehingga jumlah sampel yang dapat dipakai untuk analisis statistik sebesar 342 sampel.

Penelitian ini menggunakan kuesioner dalam pengambilan informasi dari tiap-tiap sampel. Kuesioner penelitian terdiri dari tujuh blok yang berisikan daftar pertanyaan. Setiap blok memiliki tujuan berbeda sesuai variabel yang akan diukur. Tujuh blok tersebut adalah: (I) pertanyaan mengenai identitas pribadi (nomor induk mahasiswa, kelas, umur, dsb.); (II) informasi kepemilikan smartphone, lama waktu penggunaan smartphone perhari, dan frekuensi pengecekan smartphone dalam satu jam; (III) Penggunaan smartphone diwaktu belajar; (IV) pertanyaan mengenai rata-rata Indeks Prestasi (IP); (V) Pengukuran LOC; (VI) Pengukuran kualitas tidur; (VII) Pengukuran subjective well-being. Pada bagian awal kuesioner sebelum blok I terdapat tata cara pengisian kuesioner mandiri dan pernyataan bahwa responden akan mengisi sejujur-jujurnya sesuai dengan keadaan responden yang sebenarnya.

Pengukuran variabel LOC disusun peneliti berdasarkan konsep dan definisi dari teori LOC dari Rotter (1996). Instrumen pengukuran variabel LOC menggunakan skala Likert yang terdiri dari lima pilihan tingkat persetujuan yaitu sangat tidak setuju (skor bernilai 1) sampai dengan sangat setuju (skor bernilai 5). Salah satu contoh butir pertanyaan se- bagai berikut "Saya merasa sulit mencari hal yang membanggaan pada diri Saya." Setelah itu, peneliti melakukan penyesuaian terhadap butir pertanyaan yang negatif (unfavorable) ke positif (favorable). Selanjutnya, skor pertanyaan yang merupakan data ordinal, diubah menjadi data interval menggunakan teknik deviasi normal (Azwar, 1995). Tanpa penyesuaian data ke data interval, selang interval antarbutir jawaban tiap-tiap pertanyaan tidak akan diketahui pasti. Selanjutnya, terdapat 30 butir pernyataan persetujuan yang disusun untuk mengukur variabel LOC. Sebelum dipakai, butir-butir pertanyaan tersebut diuji validitas dan reliabilitasnya terhadap 62 sampel. Setelah dilakukan pengujian validitas (keabsahan) menggunakan korelasi Product Moment (Singarimbun \& Effendi, 1989), hanya 15 butir pernyataan yang dinyatakan lolos uji validitas. Setelah itu, butir pertanyaan yang lolos diuji keterandalannya (reliabilitas) menggunakan Cronbach Alpha (Cohen \& Swerdlik, 2009). Konsistensi 15 butir pertanyaan dinyatakan baik karena nilai Cronbach Alpha lebih dari $0,60(\alpha=0,66)$, Hair, Black, Babin dan Anderson (2014).

Kualitas tidur diukur dengan instrumen penelitian yang dibuat peneliti menggunakan konsep dan definisi kualitas tidur dari DeLaune dan Ladner (2002). Setiap butir pertanyaan yang mengukur kualitas tidur berbentuk skala Likert dengan lima pilihan jawaban yang sama dengan pengukuran variabel LOC. Butirbutir pernyataan mengukur tujuh aspek kualitas tidur yang baik seperti tingkat kenyamanan, kecemasan, lingkungan, gaya hidup, makanan, penggunaan obat, dan norma budaya. Contoh butir pertanyaan sebagai berikut "Sebelum tidur, Saya mengingat-ingat masalah saat beraktivitas disiang hari." Berbeda dengan skala variabel sebelumnya, setiap butir pernyataan yang positif (favorable) disesuaikan menjadi negatif (unfavorable). Seperti skala pengukuran sebelumnya, data ordinal ditransformasi menjadi data 
interval menggunakan teknik deviasi normal. Terdapat 37 items pernyataan pada skala pengukuran kualitas tidur. Setelah dilakukan uji validitas, 20 items pernyataan berhasil lolos. Butir pertanyaan yang lolos uji memiliki konsistensi yang baik karena nilai Cronbach Alpha lebih dari 0,6 $(\alpha=0,793)$.

Variabel SWB diukur dengan instrumen penelitian yang dibuat peneliti menggunakan konsep dan definisi SWB dari Diener dkk. (2003). Setiap butir pertanyaan yang mengukur kualitas tidur berbentuk skala Likert. Contoh butir pertanyaan sebagai berikut "Dalam kehidupan sehari-hari, Saya mengalami hal-hal yang membuat saya sedih." Butir pertanyaan yang bernilai negatif (unfavorable) disesuaikan terlebih dahulu supaya bernilai positif (favorable). Seperti skala pengukuran sebelumnya, data ordinal ditransformasi menjadi data interval menggunakan teknik deviasi normal. Terdapat 54 items pernyataan pada skala pengukuran kualitas tidur. Setelah dilakukan uji validitas, 32 items pernyataan berhasil lolos. Butir pertanyaan yang lolos uji memiliki konsistensi yang baik karena nilai Cronbach Alpha lebih dari 0,6 ( $\alpha=$ 0,858).

Pengukuran variabel penggunaan smartphone diwaktu tidak tepat (khususnya diwaktu tidur) menggunakan skala Likert dengan butir-butir pertanyaan yang bersifat negatif (unfavorable). Berbeda dengan variabel sebelumnya, pertanyaan yang menjadi alat pengukuran variabel menggunakan skala perilaku, sehingga pilihan jawaban tiap-tiap butir menjadi: tidak pernah (tp), kadang-kadang (kk), beberapa kali perbulan (bb), beberapa kali per-minggu (bm), dan hampir setiap hari (hh). Rentang nilai skor adalah 1 sampai dengan 5 dengan skor tertinggi dimiliki pilihan jawaban tidak pernah dan skor terendah dimiliki oleh pilihan jawaban hampir setiap hari. Contoh butir pertanyaan sebagai berikut "Setiap sebelum waktu tidur dimalam hari, seberapa sering Anda mengecek/menggunakan smart- phone dalam sebulan terakhir?" Seperti skala pengukuran sebelumnya, data ordinal ditransformasi menjadi data interval menggunakan teknik deviasi normal. Terdapat 9 items pertanyaan pada skala pengukuran kualitas tidur. Setelah dilakukan uji validitas, semua butir dinyatakan lolos. Butir pertanyaan yang lolos uji memiliki konsistensi yang baik karena nilai Cronbach Alpha lebih dari 0,6 ( $\alpha=$ 0,727).

Prestasi belajar diukur dari nilai rata-rata Indeks Prestasi (IP) tiap responden yang dijadikan sampel. IP merupakan indikator prestasi belajar yang dapat diandalkan (Bacon \& Bean dalam Pop dkk., 2016) dan merupakan prediktor yang kuat untuk beberapa hasil penting seperti prestasi belajar (Kuncel dalam Pop dkk., 2016). Penggunaan smartphone disaat belajar sendiri diukur dengan pertanyaan "Setiap belajar sendiri, berapa kali Anda mengecek/menggunakan smartphone perjamnya" serta estimasi total waktu penggunaan smartphone didapatkan dari pertanyaan "Berapakah jam yang dibutuhkan untuk menggunakan smartphone perharinya?".

Teknik analisis. Pada penelitian ini terdiri dari dua macam analisis yaitu analisis bivariate dan multivariate. Analisis bivariate yang dipakai adalah analisis korelasi Pearson untuk mengetahui arah hubungan antarvariabel yang dihipotesiskan. Selanjutnya, analisis multivariate yang digunakan adalah path analysis (analisis jalur). Path analysis dipakai sebagai analisis utama karena teknik analisis ini dapat menguji secara simultan semua variabel yang diteliti sesuai model yang telah dihipotesiskan. Path analysis menggunakan koefisien korelasi dan regresi untuk memodelkan hubungan langsung antar dua atau lebih variabel yang diobservasi yang memiliki hubungan yang sangat kompleks (Schumacker \& Lomaks dalam Li dkk., 2015). Di dalam penelitian ini melibatkan dua variabel independen/bebas/eksogen (lama waktu penggunaan smartphone dan LOC) dan lima 
variabel dependen/terikat/endogen (penggunaan smartphone saat belajar sendiri, penggunaan smartphone diwaktu tidur, kualitas tidur, prestasi belajar, dan SWB). Diagram yang menunjukan hubungan antarvariabel yang dihipotesiskan dapat dilihat pada Gambar 1.

Path analysis memiliki asumsi dasar yang harus dipenuhi apabila estimasi yang dipakai adalah Maximum Likelihood Estimation (MLE) (Bentler \& Dudgeon dalam Hancock \& Mueller, 2013). Asumsi tersebut adalah: (1) data berdistribusi multivariate normal, (2) observasi yang independen, (3) sampel besar, minimal lima kali banyaknya parameter, (4) penentuan model yang tepat, (5) data kontinu (data skala interval atau rasio). Jika semua syarat terpenuhi maka model yang didapatkan akan asymptotic unbiased (mendekati keadaan populasi sebenarnya), konsisten (parameter hasil estimasi akan konvergen seiring meningkatnya jumlah sampel), dan asympyotic eficiency (nilai varian terkecil dibandingkan teknik estimasi lain).

Dalam pemeriksaan asumsi multivariate normal dapat menggunakan ukuran kemencengan (skewness) dan keruncingan (kurtosis) sebaran data. Salah satu teknik pengukuran multivariate skewness dan kurtosis adalah uji mardia (Ardanuy \& Sanchez, 2014). Berdasarkan hasil uji mardia menggunakan Stata/MP 14.0, sebaran data tidak mengikuti distribusi multivariate normal $X^{2}$ skewness $=$ $604,101, p=0,000, X^{2}$ Kurtosis $=254,186$, $p=0,0000$. Dari hasil tersebut, disimpulkan bahwa path analysis dengan MLE tidak dapat dipakai karena asumsi kenormalan terlanggar. Oleh sebab itu, peneliti mencoba estimasi lain yang dapat dipakai untuk data yang tidak normal.

Satorra-Bentler scaled Chi-Square (S-B Scaled $\chi^{2}$ ) merupakan teknik estimasi path analysis yang dapat menghadapi data kontinu (skala interval atau rasio) yang tidak multivariate normal. Estimasi ini melibatkan penyesuaian terhadap nilai $\chi^{2}$ MLE, kesuaian indeks, dan standar eror melalui faktor tingkatan multivariate kurtosis data yang dipakai (Hancock dan Mueller, 2013). Dengan demikian, path analysis dengan estimasi S-B Scaled $\chi^{2}$ akan dipakai untuk analisis selanjutnya.

Setelah melakukan analisis menggunakan path analysis dan telah diketahui hasilnya, tahap selanjutnya adalah memeriksa goodness of fit (kesesuaian/kecocokan model). Uji goodnes of fit digunakan untuk mengetahui apakah model statistik yang telah dibangun sudah cukup bagus dalam memodelkan hubungan antara varaibel bebas dan terikat (Liu, Lee, \& Jordan, 2016). Terdapat banyak variasi dalam pengujian kecocokan model. Lima jenis pengujian kecocokan model yang digunakan pada penelitian ini ada lima, yaitu: (1) uji $\chi^{2},(2)$ root mean square error of approximation (RMSEA), (3) tucker-lewis index (TLI), (4) standardized root mean square residual (SRMR), (5) comparative fit index (CFI). Model yang sesuai adalah model yang memiliki nilai $\chi^{2}$ yang tidak signifikan (Bryne dalam Li dkk., 2015). Bila nilai $\chi^{2}$ tidak signifikan, artinya tidak ada perbedaan yang berarti antara matriks covariance sampel dan matriks covarian model (Schumacker dan Lomax, 2016). Lalu, nilai RMSEA yang dapat diterima (good fit) adalah kurang dari 0,05 (Bryne dalam Li dkk., 2015). Nilai TLI yang dapat diterima bekisar antara 0,90 sampai 0,95 (Schumacker \& Lomax, 2016). Selanjutnya, nilai SRMR yang baik adalah lebih kecil dari 0,05 (Riadi, 2013). Terakhir, nilai CFI yang dapat diterima minimal 0,95 . Model yang sangat baik apabila nilai CFI lebih dari 0,97 (Bentler dkk. dalam Riadi, 2013).

\section{Hasil Penelitian}

Penghitungan korelasi pearson dapat dilihat pada Tabel 1. Hasil analisis korelasi menunjukan bahwa terdapat 10 hubungan antarvariabel yang signifikan pada $p$-value $\leq 0,05$. Total waktu penggunaan smartphone memiliki korelasi po 
Tabel 1. Korelasi Pearson antarvariabel di dalam model jalur $(n=342)$

\begin{tabular}{lcccccc}
\hline Variabel & Total_S & S_Study & S_Sleep & LOC & IP & Sleep_Q \\
\hline Total_S & - & & & & & \\
S_Study & $0,18^{* * *}$ & - & & & & \\
S_Sleep & $0,30^{* * *}$ & $0,22^{* * *}$ & - & & & \\
LOC & 0,02 & $-0,03$ & $-0,15^{* *}$ & - & & \\
IP & $-0,02$ & 0,00 & 0,02 & $-0,03$ & - & \\
Sleep_QQ & $-0,15^{* *}$ & $-0,09$ & $-0,36^{* * *}$ & $0,26^{* * *}$ & 0,03 & - \\
SWB & $-0,03$ & 0,01 & $-0,11^{*}$ & $0,61^{* * *}$ & 0,03 & $0,39^{* * *}$ \\
\hline Note. ${ }^{* * *} \mathrm{p}<0,001$ & ${ }^{* *} \mathrm{p}<0,01$ & ${ }^{*} \mathrm{p}<0,05$ & & &
\end{tabular}

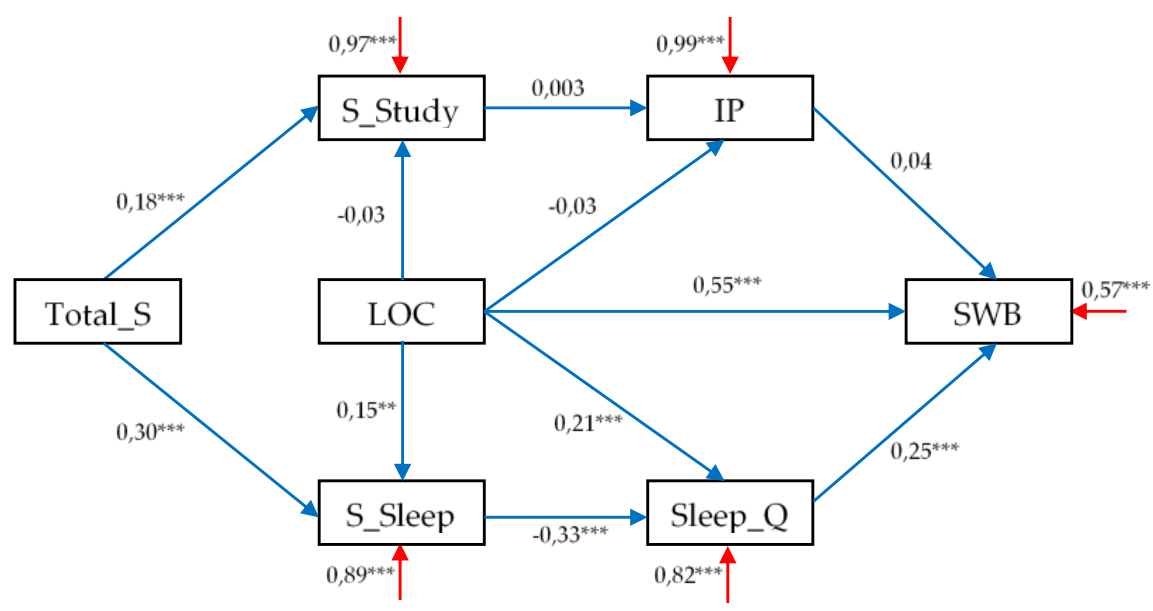

Gambar 2. Model path analysis beserta koefisien jalur yang telah distandardisasi

sitif dengan penggunaan smartphone disaat belajar $(r=0,18, p<0,01)$ dan diwaktu tidur $(r=0,30, p<0,001)$. Bahkan, penggunaan smartphone disaat belajar dan diwaktu tidur pun memiliki korelasi positif $(r=0,22, p<0,001)$. LOC secara signifikan memiliki hubungan terhadap hampir semua variabel terikat dimana semakin tinggi skornya menunjukan semakin internalnya LOC seseorang. LOC secara signifikan memiliki hubungan yang negatif terhadap penggunaan smartphone diwaktu tidur $(r=-0,15, p<0,01)$ dan berkorelasi positif terhadap kualitas tidur $(r=0,26, p<0,001)$ dan subjectif well-being ( $r=0,61, p<0,001)$. Kualitas tidur memiliki hubungan terbalik terhadap penggunaan smartphone diwaktu tidur ( $\mathrm{r}$ $=-0,36, p<0,001)$ dan positif terhadap subjective well-being $(r=0,39, p<0,001)$.
Terakhir, penggunaan smartphone diwaktu malam secara signifikan memiliki korelasi negatif terhadap subjective wellbeing $(r=-0,11, p<0,05)$. Dari hasil pengujian korelasi pearson yang signifikan, diharapkan adanya signifikansi hubungan antarvariabel pada analisis selanjutnya.

Dari hasil analisis korelasi yang signifikan, peneliti melanjutkan ke pengujian hipotesis penelitian yang terintegrasi dalam model yang dibangun. Sebelum menampilkan pengaruh masing-masing variabel yang tergambarkan dari angka koefisien yang terstandardisasi, peneliti menguji model statistik menggunakan lima uji goodness of fit. Berdasarkan penghitungan Stata/MP 14.0, nilai chisquare S-B Scaled $\chi^{2}$ model yang dibangun tidak signifikan yaitu sebesar 
Tabel 2. Sattora Bentler Scaled $\chi^{2}$ estimates untuk jalur model yang dihipotesiskan

\begin{tabular}{cllrc}
\hline Hipotesis & Koefisien Jalur & $\begin{array}{c}\text { Standardize } \\
\text { d estimate }\end{array}$ & z-hitung \\
\hline $\mathrm{H}_{1}$ & Total_S $\rightarrow$ S_Study & 0,18 & $3,29^{* * *}$ \\
$\mathrm{H}_{2}$ & Total_S $\rightarrow$ S_Sleep & 0,30 & $5,86^{* * *}$ \\
$\mathrm{H}_{3}$ & LOC $\rightarrow$ S_Study & $-0,03$ & $-0,70$ \\
$\mathrm{H}_{4}$ & LOC $\rightarrow$ S_Sleep & $-0,15$ & $-2,68^{* *}$ \\
$\mathrm{H}_{5}$ & S_Sleep $\rightarrow$ Sleep_Q & $-0,33$ & $-6,77^{* * *}$ \\
$\mathrm{H}_{6}$ & LOC $\rightarrow$ Sleep_Q & 0,21 & $4,07^{* * *}$ \\
$\mathrm{H}_{7}$ & S_Study $\rightarrow$ IP & 0,00 & 0,05 \\
$\mathrm{H}_{8}$ & LOC $\rightarrow$ IP & $-0,03$ & $-0,52$ \\
$\mathrm{H}_{9}$ & Sleep_Q $\rightarrow$ SWB & 0,25 & $5,18^{* * *}$ \\
$\mathrm{H}_{10}$ & IP $\rightarrow$ SWB & 0,04 & 0,98 \\
$\mathrm{H}_{11}$ & LOC $\rightarrow$ SWB & 0,55 & 13,40 \\
& & & & \\
\hline
\end{tabular}

${ }^{* * *} p<0,001{ }^{* *} p<0,01$

15,397 ( $p$-value $=0,0806)$. Hal ini menunjukan tidak ada perbedaan antara matriks covariance sampel dan model, sehingga model dinyatakan good fit. Lalu, nilai RMSEA lebih kecil dari $0,05(0,046)$. Model penelitian dinyatakan close fit. Nilai CFI dapat diterima karena lebih dari 0,95 $(0,976)$, bahkan sangat baik karena lebih dari 0,97 . Selanjutnya, nilai TLI model penelitian masih dalam rentang 0,90 sampai dengan $0,95(0,948)$. Model ini dinyatakan memiliki kesesuaian baik. Terakhir, badness of fit dari residual model dinyatakan kecil bila SRMR kurang dari 0,05 . Model ini memiliki badness of fit yang kecil karena nilai SRMR nya adalah 0,035 . Dengan demikian, dari ke lima uji tersebut, model jalur penelitian ini telah lolos uji goodness of fit. Model yang memiliki kesesuaian yang baik dapat menjelaskan hubungan antara variabel independen dan dependen serta unbiased dengan populasi sebenarnya.

Pada Gambar 2 disajikan hasil koefisien standar untuk semua jalur dari model penelitian yang menggunakan estimasi Sattora Bentler Scaled $\chi^{2}$. Hasil koefisien standardisasi secara spesifik ditulis pada Tabel 1. Hasil penghitungan menggunakan piranti lunak statistik yaitu Stata/MP 14 menunjukan hampir semua pengaruh antarvariabel signifikan dan sesuai dengan arah hipotesis. Penggunaan smartphone diwaktu secara signifikan dipengaruhi oleh total waktu penggunaan smartphone dan LOC, dengan koefisien jalurnya adalah $0,30(p<0,001)$ dan $-0,15(p<0,001)$. Hal ini menunjukan semakin tinggi waktu penggunaan smartphone, semakin tinggi penggunaan smartphone diwaktu tidur. Sebaliknya, semakin internal LOC seseorang, semakin rendah penggunaan smartphone diwaktu tidur. Sekitar $11 \%$ variasi variabel penggunaan smartphone diwaktu malam mampu dijelaskan oleh variabel LOC dan total waktu penggunaan smartphone. Berbeda dengan variabel sebelumnya, penggunaan smartphone disaat belajar hanya signifikan dipengaruhi oleh total waktu penggunaan smartphone $(0,18 ; p<$ $0,001)$ tidak dengan LOC $(-0,03 ; p=$ 0,242 ).

Selanjutnya, kualitas tidur secara signifikan dipengaruhi oleh penggunaan smartphone diwaktu tidur dan LOC, dengan koefisien jalurnya adalah $-0,33(p<$ 
$0,001)$ dan $-0,21$ ( $p<0,001)$. Hal ini menunjukan semakin tinggi penggunaan smartphone seseorang diwaktu tidur, semakin rendah kualitas tidurnya. Sebaliknya, semakin internal LOC seseorang, semakin tinggi kualitas tidurnya. Sekitar $12 \%$ variasi variabel kualitas tidur mampu dijelaskan oleh variabel LOC dan penggunaan smartphone diwaktu tidur. Berbeda dengan sebelumnya, penggunaan smartphone disaat belajar dan LOC tidak signifikan mempengaruhi prestasi belajar mahasiswa $(0,003 ; p=0,478$ dan $-0,03 ; p$ $=0,300)$.

LOC dan kualitas tidur mempengaruhi SWB secara siginifikan $(0,55 ; p<$ 0,001 dan 0,$25 ; p<0,001$ ), namun tidak dengan prestasi belajar $(0,04 ; p=0,165)$. Semakin internal LOC dan semakin baik kualitas tidur seseorang akan membuat semakin tinggi subjective well-being (kepuasan hidup) seseorang. $47 \%$ variasi variabel SWB mampu dijelaskan oleh variabel LOC dan kualitas tidur.

\section{Diskusi}

Berdasarkan model yang diteliti pada studi ini, terdapat beberapa pemahaman penting yang perlu dijelaskan. Pertama, variabel LOC dan total penggunaan smartphone harian tidak memiliki hubungan yang berarti. Dalam kasus penelitian ini, kedua variabel tersebut memiliki korelasi sebesar 0,02 ( $p=0,757)$. Berdasarkan temuan tersebut, peneliti membuat keputusan yang tepat untuk tidak memasangkan jalur analisis terhadap dua variabel tersebut. Hal tersebut dilakukan disebabkan peneliti berkeyakinan bahwa baik individu ber-LOC internal dan eksternal sama-sama memiliki peluang untuk meningkatkan penggunaan smartphone.

Menurut Park dkk. (2013), individu yang mempunyai LOC internal memiliki hubungan yang positif terhadap ketergantungan terhadap smartphone. Penelitian tersebut beranggapan bahwa individu ber-LOC internal bisa saja memiliki frekuensi penggunaan smartphone yang tinggi yang disebabkan oleh fitur-fitur perangkat yang memudahkan mereka untuk mengontrol kehidupan sehari-hari, misal seperti pencarian informasi, manajemen data, pengaturan jadwal harian, dan sebagainya (Park dkk., 2013). Sedangkan bagi seseorang yang tidak percaya bahwa dia memiliki kontrol penuh akan kejadian di dalam hidupnya (LOC eksternal), penggunaan smartphone yang tinggi justru memunculkan ketagihan, sehingga menimbulkan dampak negatif bagi pengguna seperti membahayakan hubungannya terhadap orang lain, pekerjaan, pendidikan, karir, dan lain-lain (Chak \& Leung, 2004).

Kedua, total penggunaan smartphone harian memiliki hubungan yang signifikan terhadap penggunaan smartphone disaat yang tidak tepat. Khususnya, peningkatan total penggunaan smartphone harian akan meningkatkan penggunaan smartphone pada waktu belajar sendiri dan disaat waktu tidur. Hasil tersebut sejalan dengan penelitian Li dkk. (2015). Selain itu, mahasiwa dengan LOC eksternal lebih mungkin untuk menggunakan smartphone diwaktu tidur dibandingkan dengan mahasiswa dengan LOC internal. Berbeda dengan penggunaan smartphone diwaktu tidur, penggunaan smartphone disaat waktu belajar sendiri tidak menunjukan hubungan yang berarti. Hal tersebut mungkin terjadi karena baik mahasiswa dengan LOC internal dan eksternal sama-sama memiliki alasan yang kuat untuk meningkatkan penggunaan smartphone nya disaat sedang belajar. Pada mahasiswa dengan LOC internal lebih mungkin meningkatkan penggunakan smartphone nya untuk menunjang proses belajarnya, seperti mencari referensi tambahan untuk membantu dalam memahami materi lebih dalam. Sedangkan untuk mahasiswa dengan LOC eksternal lebih mungkin untuk terbelahnya konsentrasi belajar karena smartphone.

Ketiga, LOC baik secara langsung maupun tidak langsung memengaruhi 
kualitas tidur. Semakin internal LOC suatu individu, semakin tinggi pula kualitas tidur individu tersebut. Hasil penelitian ini seiring dengan hasil penelitian $\mathrm{Li}$ dkk. (2015), Vincent dkk. (2013), dan Vincent dalam Vincent dkk. (2013). Peneliti berpendapat bahwa individu yang memiliki LOC internal lebih mungkin untuk tidur tepat waktu dan tidak terganggu oleh smartphone. Sedangkan seseorang dengan LOC eksternal lebih mungkin untuk terganggu oleh smartphone sebelum tidur disebabkan beberapa aktivitas yang dapat dilakukan oleh smartphone seperti jelajah internet, bermain game, bertukar pesan dengan teman, dan lain-lain.

Keempat, tidak sejalan dengan beberapa studi yakni Fini dan Yousefzadeh (2011), Chalak dan Nasri (2015), dan Majzub, Bataineh, Ishak, dan Rahman (2011) yang mengungkapkan bahwa LOC internal memiliki hubungan yang positif dengan prestasi belajar, hasil penelitian ini justru menunjukan bahwa tidak ada hubungan yang berarti antara LOC dan prestasi belajar, baik secara langsung maupun tidak langsung. Hasil penelitian ini sejalan dengan penelitian yang diteliti oleh Bozorgi (2009) yang menemukan bahwa tidak ada perbedaan yang signifikan bagi kelompok yang memiliki LOC internal ataupun eksternal dalam memperoleh prestasi belajar. Peneliti berpendapat bahwa tingginya prestasi akademik mahasiswa bisa saja dimiliki baik seseorang yang memiliki LOC internal ataupun eksternal. Bagi seseorang dengan LOC internal memiliki kepercayaan diri dalam memengaruhi proses belajarnya sendiri. Sedangkan untuk seseorang dengan LOC eksternal lebih percaya bahwa pembelajaran mereka dikendalikan oleh orang-orang dan lingkungan disekitar mereka (Bozorgi, 2009). Pendapat lain mengungkapkan, proses belajar merupakan situasi tidak selalu dapat dikontrol oleh individu baik internal dan eksternal. Apabila dapat dikendalikan (misal saja individu internal mendapatkan buku panduan belajar yang mudah dipelajari sendiri atau eksternal yang mendapatkan pengajar yang mudah dipahami), baik internal dan eksternal memiliki potensi untuk mendapatkan prestasi belajar yang sama (Bozorgi, 2009).

Kelima, secara tidak langsung, total penggunaan smartphone harian memengaruhi kualitas tidur mahasiswa melalui perilaku penggunaan smartphone yang tidak tepat, misalkan penggunaan diwaktu tidur. Terakhir, melalui prestasi belajar dan kualitas tidur, penggunaan smartphone pada waktu yang tidak tepat dan juga total penggunaan smartphone harian secara tidak langsung memiliki hubungan dengan subjective well-being (kepuasan hidup) mahasiswa.

Beberapa penjelasan diatas bila digambarkan secara singkat menjadi sebagai berikut: dengan mengamati individu dalam mengontrol penggunaan smartphone nya disaat yang tidak tepat (saat belajar sendiri dan diwaktu tidur), seseorang dengan LOC internal dapat mengurangi beberapa dampak negatif yang terjadi akibat penggunaan smartphone dengan frekuensi yang tinggi. Sebaliknya, individu dengan LOC eksternal mungkin memiliki kesulitan mengendalikan penggunaannya pada waktu yang tidak tepat dan efek negatif yang ditimbulkan akan memburuk ketika penggunaan smartphone semakin ditingkatkan. Penelitian lain bahkan mengaitkan penggunaan smartphone yang berlebihan (hingga sampai level kecanduan/ketergantungan) dengan kesehatan mental yang buruk (Harwood dkk., 2014).

\section{Kesimpulan}

Berdasarkan hasil penelitian ini dapat disimpulkan bahwa semakin tinggi penggunaan smartphone harian akan meningkatkan penggunaan smartphone diwaktu yang tidak tepat (saat belajar dan diwaktu tidur), menurunkan kualitas tidur, dan menurunkan subjective well-being. Selanjutnya, semakin internal LOC ma 
hasiswa, semakin rendah aktivitas penggunaan smartphone diwaktu tidur, semakin baik kualitas tidurnya, dan semakin tinggi juga subjective well-being nya.

Keterbatasan dan Saran. Penelitian selanjutnya diharapkan dapat mengeksplorasi faktor potensial yang mungkin dihubungkan dengan perilaku penggunaan smartphone. Dengan demikian, ada kemungkinan bahwa model statistik di dalam penelitian ini tidak lengkap dan diharapkan penelitian kedepan akan mengidentifikasi faktor-faktor tambahan untuk memperhitungkan variasi yang dijelaskan pada model tersebut.

\section{Daftar Pustaka}

Azwar, S. (1995). Sikap manusia: Teori dan pengukurannya. Ed. 2. Yogyakarta: Pustaka Pelajar Offset.

Barkley, J. E., Lepp, A., \& SalehiEsfahani, S. (2015). Collage student's mobile telephone use is positively associated with sedentary behavior. American Journal of Lifestyle Medichine, 20, 1-5. Doi: $10.1177 / 1559827615594338$

Bozorgi, S. (2009). One the relationship between locus of control and the grade point average of the Iranian Azad University Efl Students. Online Submission, 1-24. Diakses dari https://eric.ed.gov/?id=ED505569

Chak, K., \& Leung, L. (2004). Shyness and locus of control as predictors of internet addiction and internet use. Cyber Psychology and Behavior, 7, 559-570, Doi: 10.1089/1094931042403073

Chalak, A, \& Nasri, N. (2015). The interplay of locus of control, academic achievement, and biological variables among iranian online ELF learners. International Journal of Social, Behavioral, Educational, Economic and Management Engineering, 9(8), 2365-2369. Diakses dari https://waset.org/publications/10001 674/the-interplay-of-locus-of-controlacademic-achievement-and- biological-variables-among-iranianonline-efl-learners

Cohen, R. \& Swerdlik M. E. (2009). Psychological testing and assessment: An introduction to test and measurement. Ed. 7. New York: McGraw-Hill.

DeLaune, S. C., \& Ladner, P. K. (2002). Fundamental of nursing, standards and practise. Ed. 2. New York: Thomson Learning.

Diener, E., Oishi, S., \& Lucas, R. E. (2003). Personality, culture, and subjective well-being: Emotional and cognitive evaluations of life. Annual review of psychology, 54(1), 403-425. doi: 10.1146/annurev.psych.54.101601.1 45056

Fini, A. A. S, \& Yousefzadeh, M. (2011). Survey on relationship of achievement motivation, locus of control, and academic achievement in high school students of Bandar Abbas (Iran). Procedia Social and Behavioral Sciences, 30, 866-870. doi: 10.1016/j.sbspro.2011.10.168

Hair, J. F., Black, W. C, Babin, H. J., \& Anderson, R. E. (2014). Multivariate data analysis. London: Pearson Education Limited.

Hancock, G. R., \& Mueller, R. O. (2013). Structural equation modeling: $A$ second course. Ed. 2. North California: Information Age Publishing.

Harwood, J., Dooley, J. J., Scott, A. J., \& Joiner, R. (2014). Constantly connected - The effects of smart-devices on mental health. Computers in Human Behavior, 34, 267-272. Doi: 10.1016/j.chb.2014.02.006

Jacobsen, W. C., \& Forste R. (2011). The wired generation: academic and social outcomes of electronic media use among university students. Cyberpsychology, Behavior, and Social Networking, 14(5), 275-281. Doi: 10.1089/cyber.2010.0135

Klonowicz, T. (2001). Disconectented people: Reactivity and locus of control as determinants of sub 
jective well-being. European Journal of Personality, 15, 29-27. Doi: 10.1002/per.387

Lanaj, K., Johnson, R. E., \& Barnes, C. M. (2014). Beginning the workday yet already depleted? Consequences of late-night smartphone use and sleep. Organizational Behavior and Human Decision Processes, 124, 11-23. Doi: 10.1016/j.chb.2013.10.049

Lepp, A., Barkley J. E., \& Karpinski, A. C. (2014). The relationship between cell phone use, academic performance, anxiety, and Satisfaction with Life in college students. Computers on Human Behavior, 31, 343-350.

Li, J., Lepp A., \& Barkley, J. E. (2015). Locus of control and cell phone use: Implications for sleep quality, academic performance, and subjective well-being. Computers in Human Behavior, 52, 450-457. Doi: 10.1016/j.chb.2015.06.021

Liu, Q., Lee, J. D., \& Jordan, M. (2016). A kernelized stein discrepancy for goodness-of-fit tests. Proceedings of the 33rd International Conference on Machine Learning. The 33rd International Conference on Machine Learning, 48, 1-9. Diakses dari https://arxiv.org/abs/1602.03253

Majzub, R. M., Bataineh, M. Z., Ishak, N. M., \& Rahman, S. (2011). The relationship between locus of control and academic achievement and gender in a selected higher education institution in Jordan. Proceedings of the 8th WSEAS International Conference on Education and Educational Technology. 215-220. Diakses dari https://www.researchgate.net/public ation/267243308_The_Relationship _between_Locus_of_Control_and_A cademic_Achievement_and_Gender _in_a_selected_Higher_Education_I nstitution_in_Jordan

Naibaho, M. L. A. (2013). Hubungan kualitas tidur dan daya ingat pada
Mahasiswa Program Sarjana Fakultas IImu Keperawatan Universitas Indonesia. (Skripsi tidak dipublikasikan). Fakultas IImu Keperawatan Universitas Indonesia, Depok.

Park, N., Kim, Y. C., Shon, H. Y., \& Shim, H. (2013). Factors influencing smartphone

Pop, E. I., Negru-Subtirica. O., Crocetti E., Opre A., dan Meeus, W. H. J. (2016). On the interplay between academic achievement and educational identity: a longitudinal study. Journal of Adolescence, 9(8), 1-10. doi: 10.1016/j.adolescence.2015.11.004

Riadi, E. (2013). Aplikasi lisrel untuk penelitian analisis jalur. Yogyakarta: Andi Offset.

Rotter, J. B. (1966). Generalized expectancies for internal versus external control of reinforcement. Psychological Monographs: General and Applied, 80(1), 1-28. Doi: 10.1037/h0092976

Sahin, S., Ozdemir K., Unsal A., \& Temiz, N. (2013). Evaluation of mobile phone addiction level and sleep quality in university students. Pakistan Journal of Medical Sciences, 29(4), 913918. Doi: 10.12669/pjms.294.3686

Schumacker, R. E., \& Lomax, R. G. (2016). A Beginner's Guide to Structural Equation Modeling. Ed. 4. New York. Routledge.

Singarimbun, M. \& Effendi, S. (1989). Metode penelitian survai. Jakarta: LP3ES.

TNS Infratest Germany. (2015). Smartphone Usage (\%): Indonesia. Diakses 12 Februari 2016, dari use and dependency in South Korea. Computers in Human Behavior, 29,

Vincent, N., Walsh, K., dan Chiang, D. (2013). Control and coping in chronic insomnia: A daily diary study. Behavior Research and Therapy, 51, 240-246. Doi: 10.1016/j.brat.2013.02.004

Vserv. (2015). Vserv unveils the first Smartphone User Persona Report 
(SUPR) in Indonesia. Diakses 12 Februari 2016, dari first-smartphone-user-personahttp://www.vserv.com/vserv-unveilsreport-supr-indonesia/ 